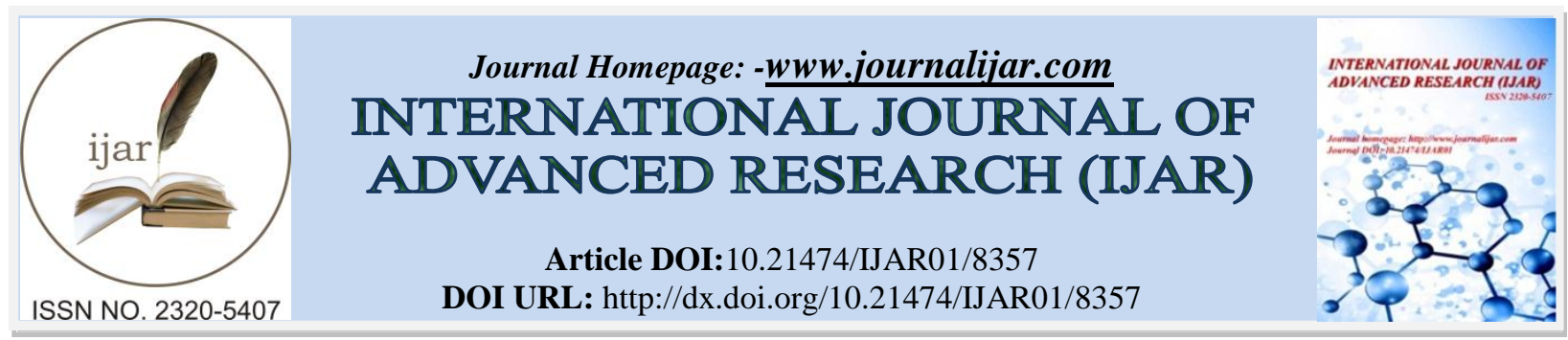

RESEARCH ARTICLE

\title{
A PERVASIVE REVIEW OF THE CUSTOMER CONTENTMENT IN THE BHILWARA BANKING SECTOR.
}

Asif Perwej.

Assistant Professor, School of Management Studies, Sangam University, Bhilwara, Rajasthan, India.

\section{Manuscript Info}

Manuscript History

Received: 08 November 2018

Final Accepted: 10 December 2018

Published: January 2019

Key words:-

Servqual model, Bhilwara, Customer contentment, Service-profit chain, Banking sector, Gap model.

\section{Abstract}

The customer contentment is one of the most significant factors in business. When it comes to commercial banks, customer contentment level disassemble one bank from another, thus measuring customer contentment is exceedingly important. The main aim of the research is to calculate the determinants of customer contentment on higher service quality in the Bhilwara banking sector. In thispaper SERVQUAL model is used to analyses the perception of customers on determinants of service quality. The total of 150 customers of the major banks in Bhilwara city has been surveyed. The experiential analysis is carried out by SPSS and outcome reveal that customer contentment in the banking sector depends on good and firm relations, building faith between customers and bank employees in the case of Bhilwara city. The bank should emphasize the importance of customer contentment among its employees and take further actions in order to ameliorate the quality of service.As the main concentrate on satisfying the customer who demands to put an extra effort to comprehend their concerns. Infrequently a little node or a smile can make a customer feel valued. There are small things like gestures, the way of dealing even dressing can be used as impetus technique. In addition,it's important to deal with the customer in a way he/she understands. If we consider banks, particularly, people who visit the bank belong to different age groups so bank should deal them in their way according to their convenience level.

Copy Right, IJAR, 2017,. All rights reserved.

\section{Introduction:-}

The big data dramatic change in and around 21st century has found a resonance with banking firms, considering the valuable data they've been storing since many decades [1]. Banking as a data intensive subject has been progressing incessantly under the promoting impact of the era of big data. This data have now unlocked secrets of money movements, helped inhibit major disasters and robbery and understand consumer behavior. In today's world competition among the companies is very severe, but most of the company'scurrent nearly the same product or service with their opponent [2]. In order to distinguish from a competitor's a firm needs to offer preferable services [3]. The contentment is a crucial concern for both customers and organizations including banks.

The customers on the hand want the get the better of value for their money. Consequently, they spare no endeavor in searching for high quality services [4]. Customers' perceptions are determined by innumerable of factors. The

Corresponding Author:-Asif Perwej.

Address:-Assistant Professor, School of Management Studies, Sangam University, Bhilwara,

Rajasthan, India. 
individual's consumption behavior is making an impression by personal characteristics like age and life-cycle, occupation, economic circumstance, lifestyle and personality and self-concept [5]. It is known that higher service quality leads to more contented customers and higher customer contentment leads to customer allegiance. Sustain quality takes the stage and offers more contented and loyal customers, and in return more benefit is gained than to your competitors. The purpose of this study is to evaluate the determinants of customer contentment and the influence of service quality in the Bhilwara banking sector. The customer contentment is linked to customer loyalty and customer loyalty is linked to the benefits of a bank. The customer contentment is an essential aspect for service organizations and is highly associated with service quality, they are all associated with each other, as service quality gets superior, customer contentment level will also be increased and it will lead to more lasting relationships between a bank and its customer leading to a higher level of allegiance as well as beneficial.

\section{Related Works:-}

The Hartl et al. [6] posit that behavior of consumers is not predictable sincetheir preferences are becoming more complex and discriminate. Their demand for sensory, health, process and facility qualities have become more heterogeneous. Smith et al. [7] individuals differ from one another and even perceive the same thing disparately. The Engel et al. [8] Culture has a great influence on a person's consumption behavior. The cultural factors are divided into two, first sub-culture and second social class. Solomon et al. [9] indicate that culture is the values, plan and symbols that enable people to communicate, interpret and evaluate as members of society.Concerning with the studies done by parasuraman et al. [10] a service quality model is developed and the outcome of the expectations and perceptions of the customers can be analyzed.According to Asif Perwej et al. [11] focuses that the data mining technique, neural networks can be used for further research in ERP-CRM integration. This can be used in any kind of industries which has CRM and ERP departments. It helps to take valuable and optimal decisions on the customer side as well as for the entire management system. Lewis et al. [12] Service quality is the evaluation of customers' expectations that has fulfilled and how goodthe service level delivered. Delivering quality service means complying with customer expectations on a coherent basis. Heizer et al. [13] complicated character of services comes out from their common features, which are perishability, intangibility, high customer involvement, simultaneous production and consumption and homogeneity.Service quality is more arduous for the consumer to appraise than better quality. Service quality perceptions outcome from a collation of consumer expectations with actual service performance and quality evaluations are not made just simply on the outcome of a service, they also contain evaluations of the continuum of service delivery.In the opinion of to Asif Perwej et al. [14] research is an effort to evaluate the service quality of the private banks in India. The study is based on primary data collected in the cities of Delhi and NCR through a structured questionnaire designed on the basis of SERVQUAL Model. The banks under study are the five top private banks from Delhi and NCR region. The study has found that none of the banks have been able to meet the customer expectations and are still abode on the 'zone of pain'.Wang et al. [15] features combined with the accelerating significanceof the service sector, have also boosted the necessity for better service quality as corporations search for methods to cultivate financial performance and captivate customers in a very competitive environment.

According to Solomon et al. [9], there are different types of customers or consumers. They may be grouped, individuals, nations, communities or organizations. The banking industry like any other industry has raised its efforts to satisfy consumers via the provision of quality services. These stem from that fact that competition has been stiff and every bank is trying to keep hold of old customers and woo new ones.Parasuraman et al. [10] SERVQUAL method uses these 10 aspects. It evaluatesthe gap between customer expectations and experience. The basic assumption of the measurement was that customers can evaluate a firm's service quality by comparing their perceptions with their expectations. The Metawa et al. [16] submit that the quality of service is a function of the experience of customers since services must be used first.In the opinion of Burke et al. [17] service purchase is various from a product. There is no contact with the organization selling the product and the consumer and therefore the perceptions of the quality of the product are not induced by the people in the organization. The consumer forms his decision about the quality of the product based on advertisements, recommendations by individuals who have used the product previouslyor the experienced he has had after using the product in the previous.Abdullah et al. [18] draw attention to that the level of customer contentment may be influenced by several internal and external factors.

These propose that the determination of contentment is very arduous.According to Curry et al. [19] SERVQUAL is to have a standard and a credible tool that can be used to measure the quality of services in various service sectors. In the beginning, those who developed SERVQUAL introduced ten service quality dimensions or attributes. These 
are responsiveness, competency, courtesy, tangibles, reliability, communication, credibility, security, access and understanding the customer.

\section{Axiomatically of Service Quality:-}

The ten axiomatically of service quality is given. The first determinant is the containexpansion of performance and dependability. That means that the firm performs the service properly as righteousness in billing, keeping records advisably and services are accomplished in appointed time. The responsiveness anxiety the willingness or voluntariness of employees to provide service. It contains up-to-datedness of service, turning to anappeal as soon as possible, realizing repugnant mistakes swiftly and fixing it, serving fast and being punctual [20]. The competence means having the needed and asked skills and knowledge to executethe service. It contains knowledge and skill of the contact personnel, knowledge and skill of operational support staff, research capability of the organization, for instance searching for the most profitable stock on the market for customers. Access involves reachable and easy to communicate. It means the service is that is comfortably accessible by telephone, waiting time to receive service is not prolonged, appropriate opening and closing hours,appropriate location of service institution. The courtesy concerns esteem, respect, prominence, kindness, decency, and friendliness of contact personnel. It includes consideration for the consumer's commodity, clean and neat appearance of public contact personnel. The exchange of information with customers by oral language by using a clear and understandable language, and give time to hear them. It can also mean you need to verify the language you are using according to the level of education, intellectuality and status, because these vary from individual to individual. The credible means faithfulness, reliability, stability, honesty and integrity of the institution. Security means no threat, damage, risk, uncertainty. It involves physical safety, such as financial security, confidentiality [21]. Understanding the customer involves making the effort to understand the customer's requirement. It involves learning the customer's specific requirement and wants, giving personalized observation and care, recognizing the regular customer. Tangibles include the physical proofof the service as physical facilities, [22] appearance of personnel, tools or equipment used to provide the service, physical representations of the service, like as a credit card or a bank statement. Concerning with the [23] determinant in their studies scholars discover that the search and necessity for higher service quality, apply companies seek for ways to develop financial performance and offering consumers in a very competitive market [15]. Services that are impalpable make it hard to have an understanding of how it is perceived by customers. If a service provider is familiar with how the service will be appraised by customers, then they will be able to impress these evaluations in a positive way for the advantage of the company itself. The "word of mouth" has a lot more valuable effect on potential consumers than marketing strategies that they are used to. The service quality studies necessity to be done according to customers' perspective [24]. The correlation between these two constructs and recommended by going and mediator model later studied and analyzed [25].Theconsumers infrequently tend to purchase based on their evaluation of the value of services in place of trending directly to buy optimal service quality. This tendency stresses the prominence of the value and by the light of that, researchers inset model value for improvement and understanding of service quality [26].

\section{Customer Contentment Effect:-}

The customer contentment does have a positive effect on an organization's profitability. The contentment customers form the foundation of any successful business as customer contentment leads to repeat purchase, brand allegiance, and positive word of mouth [27]. The customers, company, and competitors, the 3 C's procedure [28], as potential determinants of the satisfaction loyalty connection. We will be examining all the determinants of these connections, including customer buying perception, expectations, and habits, sources of information, positive word of mouth, service quality, contentment and allegiance. The customer contentment leads, customer allegiance and customer allegiance bring profitability. They are all belonging to one another. Therelationship of customer contentment [29] to customer retention in banking [30]. All these people work on the connection between profitability, allegiance and contentment [31].The figure 1 presents a Relationship between service quality and customer contentment. This model is constructed after going through various models related to service quality and customer contentment. According to figure somehow personal and circumstance factors also affect the process of customer contentment. The figure 1 presents a model that describes the factors affecting service quality and customer contentment relationship and improvement master plan. The model is categorized in three parts. The first part describes the relationship between service quality and customer contentment, the second part definesthe factors affecting service quality and customer contentment and the third part define the service improvement strategies or techniques at three levels [10]. The model first describes the relationship between service quality and customer contentment by describing the drivers of service quality and customer contentment that leads to customer compatible or incompatible responses related to their repurchase or switching intensions. Secondly the model definesthat service 
quality and customer contentment further affected by several other elements ,like quality of service are affected by the way service providers interact with the customers, physical environment, design and decor elements, employee appearance and the appearance of the equipment. On other hand customer contentment is affected by the value, transaction contentment, Firm's [10] corporate reputation or image, performance and price factor. Besides the model depict that quality of service can be made better in the organization at three levels, by developing service improvement strategies, by managing the workforce and by closing the gaps between firm's perception and customer perceptions of the standard.

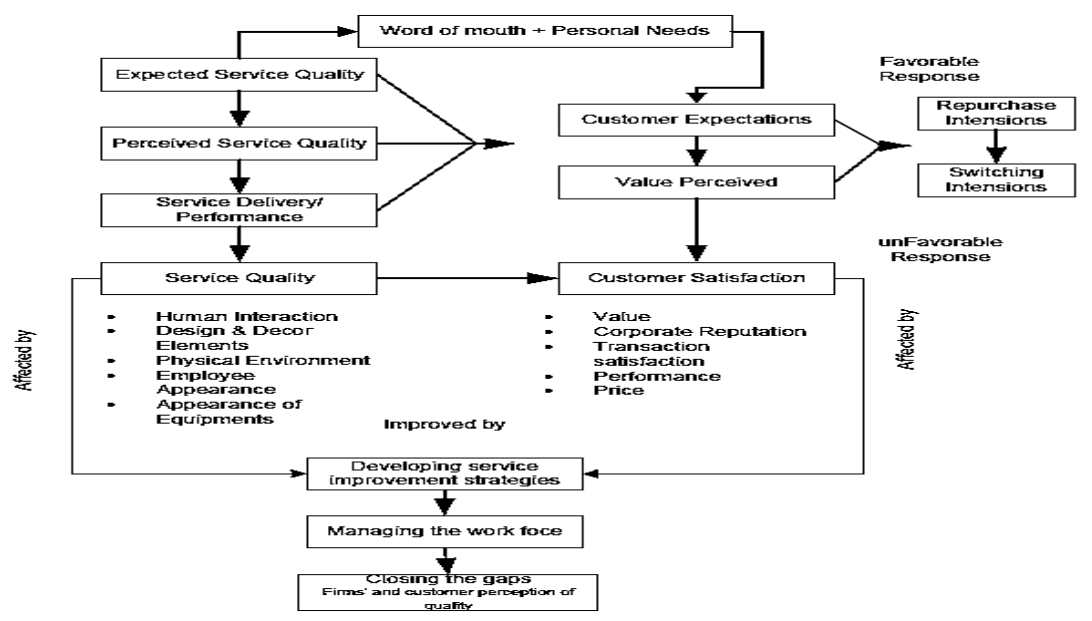

Figure 1:-Factors Effecting Service Quality (FESQ) and Contentment Relationship Model

The Servqual Measurements:-

The SERVQUAL model was developed by Parasuraman, Zeithaml and Berry [10] to identify five various gaps between customers' expectation and service that is provided by a company. Customer expectations mean aspiration and hopes they have prior to the service and perceptions mean evaluation of the service that have been provided. If expectations are greater than the genuine performance, then customer discontent occurs. On a contrary, the smaller these gaps, the preferable service quality are. As it is shown in figure 2, the model measures five gaps that enable to analyze the service quality from the customerviewpoint [32].

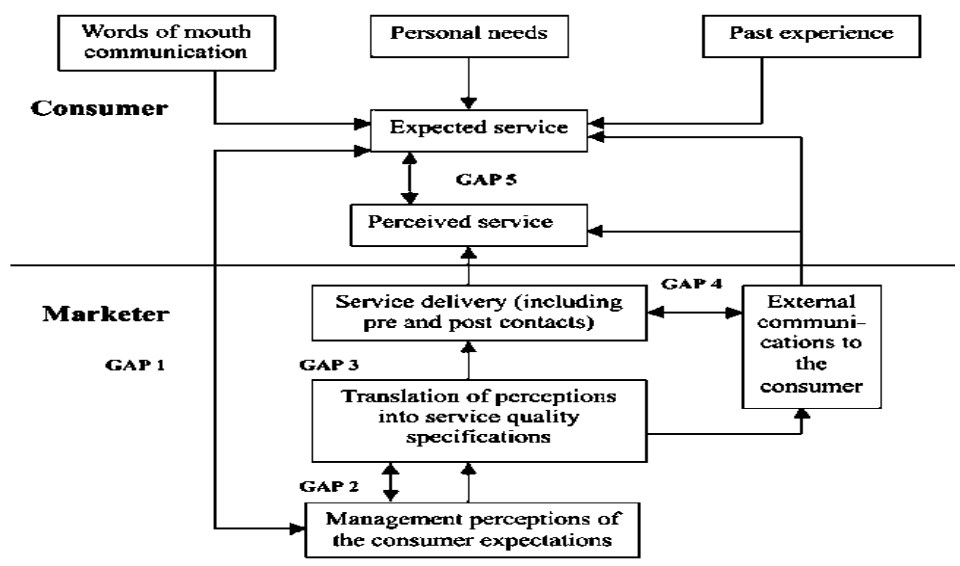

Figure 2:-The Gap Model of Service Quality

GAP 1 (Expected Service):-

The GAP 1 shows the gap between customer expectations and how management sees those prospects. The gap become visible when managements do not understand customer wants and aspirations. It is likely to happen in companies with lack of better customer contentment research. Besides, bureaucracy is also accountedfor a big gap since it is an ineffective way of communication. To keep away from the gap, the company should always conduct various researches and be aware of customer expectations. A company that is conscious about the gap should seek the best ways to get in touch with customers and become conscious of their expectations. To keep the gap small, a 
company should objective of building strong relationships with customer's, keep away from many layers of management and develop an effective way of upward communication [33].

\section{GAP 2 (Management Perception):-}

Understanding customer needs is very essential, though companies also need to know what kind of services should be endowed to customers. The GAP 2 becomes visible when services are designed without thinking about customer necessity. It can become visible because of insufficient service scope, absence of goal settings or unfair task standardization [33]. To make the gap concise, a company should develop measurements to measure customer perception and company's performance.

\section{GAP 3 (Service Delivery Gap):-}

Even if a company has obstructed the first two gaps, it may still have issue providing services that meet customer expectations. The GAP 3 becomes visible when the company lapse to deliver services in the way that customer's necessity. The gap indicates that delivered service did not match the norms. It happens due to lack of success to analyze and match the supply and demand, as well as incapacitated human resource policy. To obstruct this gap, companies should build their master plan around delivering transcendent service. In the GAP service is delivered as it was designed when employees are motivated and are able to deliver quality service. A company should appoint people with essential skills and interest in doing the work.

\section{GAP 4 (Service Delivery):-}

When a company has done everything to obstruct previous gaps, there is still a risk of lack of success to meet customer expectations, if the service that is delivered does not match with communications about it [33]. When companies advertise the services todissimilar media, customers expect the quality of services to be as assured. Apart from that, customers are discontented and consider the quality of service nethermost. In consequence, companies should focus on developing plans to reach customers in order to provide services in the right way

\section{GAP 5 (Expected Service):-}

The foregoing gaps create the GAP 5, which define the disparity between expected services and the perception of the received service. The key to cessation the GAP 5 is too close foregoing four gaps. The companies should carry out various researches to know customer expectations while working with employees to provide the proper service at the proper time.

\section{The Aim of the Study:-}

In this paper, this study service quality model is produced and research hypothesis of the study are provided based on the literature review,consequently service quality model and then hypothesis regarding this model will be given. The main aim of the service quality model is that consumers' quality perceptions are affectedby a series of segregatinggaps occurring on the marketer's side. A key challenge for researchers is to devise procedure to measure these gaps appropriately. In this paper needed to examine the nature of the association between service quality as perceived by consumers and its determinants. The importance of segmenting consumers on the basis of their service quality expectations deserves exploring [33]. In view of the fact that, services are intangible, it is really hard to measure their quality. In order to have an understanding of how a service is perceived by a customer service quality procedure has to be used. The SERVQUAL method uses tenaspects called "service quality determinants". These aspects help to evaluate the dissimilarity or gap between customer's expectations and perceived value at the end. Therefore of services are intangible, it is really hard to measure their quality. In order to have an understanding of how a service is perceived by a customer service quality process has to be used.

\section{The Service-Profit Chain:-}

The service profit chain was first developed by Heskett, et al. [34] who stated that there are powerful relationships between benefit, customer allegiance, customer contentment, revenue growth, employee capability, the value of goods and services delivered and productivity. As it is shown in figure 3 , hisobjective of the service profit chain is to create a working environment within a company where highly motivated and contented employees interact with customers and create preferable customer experience. It shows that advantageous business and revenue increase is possible only if the service is provided by contented employees. The element on the right side such as revenue growth and profitability indicate that a company's value is determined by customer value. 
Internal

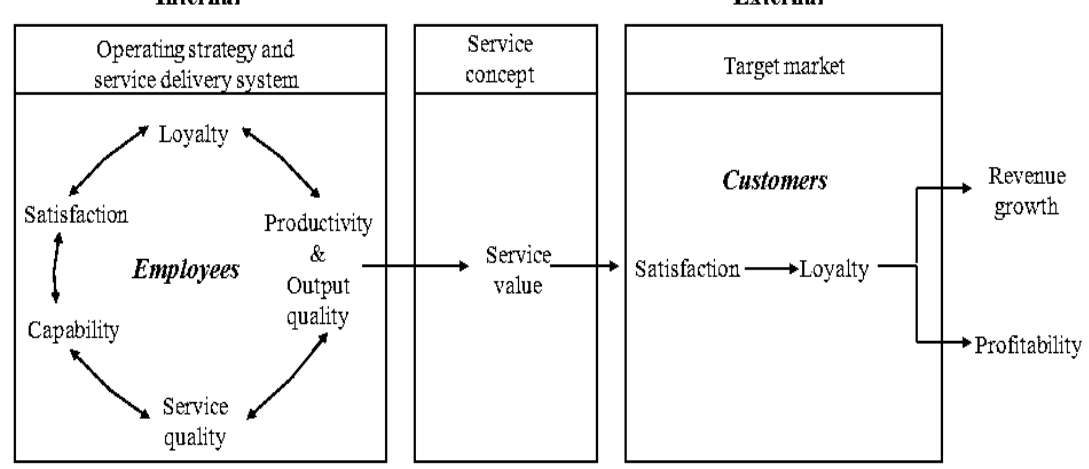

Figure 3:-The service-profit chain

The elements on the left side describe how customer value is created the higher the loyalty of customers, the more precious the relationships, the customer is more contented and stalwart and the superior service is perceived, the more contented customers will be [35]. Simply put, customers assess services and when the estimate is positive, customers become stalwart. As anoutcome, it'sgrowth the company's value. In companies where the service-profit chain is applied, more customers are stalwart and they buy more and tell others about the company and positive experience. The company should develop various plan and policies to support employees, since they deliver company's values to customers. The level of employee contentment is measured by feelings they have about their jobs and relationships with other staff.

\section{The Hypotheses, Data and Methodology:-}

In order to inquire into the relationship between customer contentment and allegiance with the help of service quality and positive word of mouth, the following hypotheses have been developed by using 10 phasesof service quality determinants by using a query in the survey. A sample of 150 customers of various banks completed the questionnaires concerning the customer contentment and allegiance in banks in the Bhilwara city. The survey consists of twelve parts. In the first six parts participants'level of education, age, gender, marital status, citizenship and monthly income level are located. Of the six till the ninth part questions about number of banks that the customers work with, which banking channel they are using and the often of usage located. From the tenth question till the end questions of, why do you choose to use this channel, why do you prefer to work with that bank specifically, what do you pay attention more in a branch, what are the most vital expectations from the staff of a bank, are located. Questionnaire of this research is available upon entreaty.

\section{Competence:-}

In the competence question number 28 shows supposing the teller and customer representative has adequate product knowledge have been used in order to measure the significance of the knowledge and ability of the personnel for customers.

\section{Access:-}

In the access questions numbers $8,9,10,13,17,32,37$ shows Internet banking is very advanced, endows convenient and secure use, has so many branches all over, i can have all my transactions made by telephone banking, has so many ATM in many places, menus can comfortably be understandable, again, i don't wait too much in line in the branch, supposing the branch is crowded or deserted, and every time be reachable, has been used in order to measure the importance of being reachable and trouble-free to communicate for staff and even for the all bank's services for customers.

\section{Courtesy:-}

In the courtesy questions numbers $18,19,20,21,25,41$ shows me individual attention, supposing the tellers are polite and patient or not, to hear the words of welcome, good morning and goodbye, how the watchman welcomes me and the way he use while doing that, are they being formal when they are talking to me, are the branch staff are polite and formal while they are talking to each other, has been used in order to measure the importance of gentleness, amiability of contact personnel for customers. 


\section{Reliability:-}

In the reliability questions number 48,50 shows even very engaged at that moment, afterwards takes care of my transaction and inform me about what happened, and keep his \&her assurance at the specified time frame, has been used in order to measure credibility of the personnel.

\section{Responsiveness:-}

In the responsiveness questions number 16, 38, 39 shows the branch personnel areresponsive, courteous and supporting, give substitute and practical solutions for me, notify me about my products constantly with detailed, has been used in order to measure liable, readiness of employees to provide service.

\section{Communication:-}

In the communication questions numbers 15, 47, 49shows i see advertisedin the newspaper veryfrequently, look at my face while i am talking, doesn't speak with an irate expression or high volume, has been used in order to measure the importance of being touched with customers by oral language by using anapparent and comprehensible language for customers.

\section{Credibility:-}

In thecredibility questions numbers 22, 23,27,29,30,33,35, 36 shows branch personnel areconversable and downstage, the relation that I have established with staff in years, my family and my friends use this bank, inasmuch as i don't like the bank any more, icannot leave because i have been working for so many years with them, they give reduction and my demands are swiftly met because $i$ have been working with them too many years, if the staff is serving with a smiling face or not, not to be gloomy, should not seem or sound that he\& she is board in front of me, has been used in order to measure the importance of faithfulness, credibility, steadiness, honesty and inte grity of the staff and bank itself for customers.

\section{Security:-}

In the security questions numbers $6,14,26,46$ shows $i$ find it more secure, $i$ am happy with the bank's services in general, if the tellers are doing all the transactions very swiftly or not, do my transactions swiftly and rightly, has been used in order to measure the importance of hazard and unpredictability of the staff and bank itself for customers.

\section{Understanding and Knowing the Customer:-}

With the understanding and knowing the customer questions numbers 34, 40, 42, 43, 44, 45 shows do they keep in mind my name after going more than once, recognize me and call me by my name, to understand what product do $i$ need, not to sell a product that i don't want to use, ask me how i am, pays attention to me, ask me if I want a liquid refreshment, has been used in order to measure the importance of understanding the needs of the customers for customers.

\section{Tangibles:-}

In the tangibles questions numbers 24, 32 shows branch is very neat and tidy, is the staff cloths are tidy and clean, has been used in order to measure the importance of physical verification of the service for customers.

\section{Recommendation:-}

\section{For Managers:-}

The service quality and customer contentment are proved to be the important determinants to sustain the overall performance system of the firm. Managers should systematically monitor and ameliorate all channels via which product\& service pass perpetually. For this intention capacity planning of employees is essential to avoid stressful circumstances. It can be done by setting employee targets to be attained daily to measure over and under capacity of their work. The capacity planning help in setting targets and measuring the performance by evaluating the amount of work employee can deliver each day. These services can be done better by aligning the functions of all the departments and by organizing the intercommunications between cross functional departments in a timely manner. Also, it is essential to measure employee performances on monthly or quarterly basis. The quality inspection and measurements on a monthly basis can assist to grow the quality standards. Employee motivation is a key thing to attain organizational goals and aim. To trigger employee motivation, award system should be introduced in the workplace. The developing a framework for employees by setting the example of behaviors to be followed by the managers can really help in these respects. 


\section{The Outcome:-}

According to these conclusion 150 respondents,58.2\% are men and $41.8 \%$ are women. The $79.6 \%$ of them are wedded and $20.4 \%$ are single. Concerning with the education level, it can be seen that half of the answerer hasa university degree. The $6.1 \%$ persons education was high school level, $40.8 \%$ interlevel, $39.2 \%$ graduatelevel, $13.9 \%$ master level.26.4\% in between 18-24 years old, 34.6\% 25-38, 21.9\% 39-50, 14.1\% 51-60, 3\% 61-75 and more years old.In the earnings level 43.2\% are in between 10000-20000 INR, 25.4\% 20000-40000 INR, 14.4\% 4000080000INR,9\% 80000-120000INR,8\% 120000- 200000 and moreINR.Using the bank 42.8\% uses only one bank, $22.2 \%$ two banks, $17.1 \%$ three banks, $9.6 \%$ four banks and $8.3 \%$ uses five banks. The $38.7 \%$ prefers to use the internet as banking system, 48.1\% ATM,13.2\% telephone banking. The preference of the branch, $38.4 \%$ persons prefers branch, $32.3 \%$ use that visit once in a month,43.7\% few times in a month, $18.3 \%$ once in a week, $4.5 \%$ few times in a week and $1.2 \%$ uses per day.

\section{Conclusion:-}

In this paper, we are investigating the interaction between customer contentment and loyalty factors, service quality and positive word of mouth impacts on the sample of 150 customers of various banks in Bhilwara. According to the outcome, the overall customercontentment is above average. The outcome shows that necessity and word of mouth affect the level of customer expectations and cognition about the quality of service which leads to overall customer contentment \&discontentment. A need drives the customer to buy whereas word of mouth has the power to transform customer perception and expectations concerning the bank service. It was found that service performance and negative word of mouth has the strongest influence on customer decision concerning continuing (repurchase intention) or discontinue (switching intension) the relationship with the particular service provider.According to these outcomes we can summarize some demographic data and liking. The majority of man and woman who has answered the survey are nearly identical. As we can see education level is high in these 150 customers. The majority of them are in between 24-46 years old and income level is high. The majority of them use one or two banks and many of them nearly half of the respondersprefer to use branch and usage conservation is very high. Pursuant to descriptive statistics of the related 50 questions of the survey in the light of Likert Scale 1 via5 with importance scale respectively we can come to some conclusions. In the light of descriptive statistics the outcome can be summarized as follows at first in Bhilwara most of the people still depends on the branches, they prefer it mostly because they quest it more secure and friendly service makes them to stop by to branch frequently and in view of the fact that, the lack of traffic congestion in Bhilwara they quest very easy. Bhilwara is a small city, no traffic jam, no need to rush and everywhere is close to each other so people are able to reach branchescomfortably.

In the Bhilwara people care about each other, sensitive to others and develop friendships while they are doing business. So they see the bank personnel as a friend of them, develop faith and retain good relations. Bhilwara peopleinquire this from personnel to perform it with a smiling face and not to be gloomy. They always want to be in contact with an employee of the bank, at least able to reach him \&her whenever assistance is needed. They want to be unequivocal as what they necessity, when they necessity and how much they necessity. They want their name to be remembered and to be asked how they are, do they need any assistance or anything to drink while they are waiting. Till this point as we see most of the expectations are associated with personal needsfor instance,to be respected, to be understood, like to be cared, to have sincere relations, these are the needs of the people in Bhilwara city.In the banking industry,we are all tellers,salesperson, portfolio managers even branch managers. We all try to sell bank's products (for instance saving account, credit card, loan, direct debit, online banking) and do marketing for the services of the bank. In order to do that, we requirement to have a better understanding of customer's needs and wants. If we can establish a direct bond with a customer need and aspiration, we will absolutely be victorious. Pursuant to the outcome most of the customers who use only one bank is a woman. The majority of online banking users are man, this can lead to the outcome of men are more technology oriented. The majority of older people prefer to use branch and nearly the other rest uses ATM's mostfrequently. Online banking users use the internet very frequently, the few customers'investigate not just only their accounts they also keep up with exchange rates or stock market movements. The youthful customers tend to use net banking, mobile banking, ATM and branch respectively with the usage frequency. In usual study findings show that people want to be cared, listened, respected and be remembered. If any company can actualize and fulfill these needs, the customers of them will be pleased and be life time customers. In this context, toameliorate performance system companies are striving to focus more on introducing employee oriented policies by restraining the gaps between management employees and its customers. The service quality management gap can be eliminatedby planning the activities, via research and analysis and by arranging the staff properly company can analyze and predict customer expectations. Additionally, it is essential to develop customer general mapping, database analysis, capacity planning and focus attention on marketing research 
and analysis to gather information about ultramodern market trends.

\section{References:-}

1. Yusuf Perwej, "An Experiential Study of the Big Data," International Transaction of Electrical and Computer Engineers System (ITECES), USA, ISSN (Print): 2373-1273 ISSN (Online): 2373-1281, Vol. 4, No. 1, page 1425, March 2017, doi.org/10.12691/iteces-4-1-3

2. Zopounidis, C. 2012. New Trends in Banking Management. Luxembourg, Springer Science \& Business Media

3. Asif Perwej, "Effective Management of Customer Relationship Management (CRM) In Banking Industry," YOJNA The Management Journal of KITE Group Vol. No. 2 \& 3, No. 1, ISSN 0974 -7079 YOJNA, Dec 2010

4. Strategic Direction, the Retail Banking Industry in 2015: Trends and Strategies to Focus on and Develop, Strategic Direction, 23(6), 32-34, 2007

5. Kotler, P., Marketing Management, New Jersey, Pearson Education, 11th ed., 2003

6. Hartl, J.,The Changing Consumer: Demanding but Predictable,International Food and Agribusiness Management Review 9(2), 88-93, 2006

7. Smith, G.T., Why Do Different Individuals Progress Along Different LifeTrajectories? Perspective on Psychological Science Journal 4(4), 415-421, 2009

8. Engel, J.F., Blackwell and Miniard, P.W., Consumer Behaviour,Orlando, The Dryden Press,1993

9. Solomon, M., Bamossy, G., and Askegaard, S., Consumer Behaviour: AEuropean Perspective, New Jersey, Prentice Hall Inc., 1999

10. Parasuraman, A., Zeithaml V. A., Berry L. L." A conceptual model of service quality and its implication for future research" Journal ofMarketing, Vol. 49, No. 4, pp.41-50, 1985

11. Asif Perwej, "Analytical Study for Seeking Relation between Customer Relationship Management and Enterprise Resource Planning," IJACM , International Journal of Arts Commerce \& Management, VOL.10 No. 01, pp 6-8, June 2011

12. Lewis, Robert C. and Bernard H. Booms, "The Mar-keting Aspects of Service Quality," in Emerging Perspectives on Services Marketing,L. Berry, G. Shostack, and G. Upah, eds, 1983

13. Heizer, J.H. and Render, B. , "Operations Productivity", Principles of Operations Management.USA: Printece Hall, pp 1-68, 1999

14. Asif Perwej, "The Impact and an Analytical Study of Service Quality Measurement in Leading Private Banks of India in Delhi and NCR Region," International Journal of Computer Science and Telecommunications , www.ijcst.org, Volume 3, Issue 12, PP 32-38, December 2012

15. Wang, J., Public diplomacy and global business. Journal of Business Strategy, 27(3),41--49, 2006.

16. Metawa, S.A. and Almossawi, M., Banking Behavior of Islamic BankCustomers: Perspectives and Implications, International Journal of BankMarketing 16(7), pp 299-313, 1998

17. Burke, R., J. Graham, J and Smith, F.J., Putting the Customer Second,The TQM Magazine 17(1) pp 85-91, 2005

18. Abdullah, D.N.M.A. and Rozario, F., Influence of Service and ProductQuality towards Customer Satisfaction: A Case Study at the Staff Cafeteria inthe Hotel Industry, World Academy of Science, Engineering and Technology 53,pp185-190, 2009

19. Curry, A. and Sinclair, E., Assessing the Quality of PhysiotherapyServices Using SERVQUAL, International Journal of Health Care QualityAssurance, 15(5), 197-205, 2002

20. M. Mohsan K., Saida S.,"Determinants of service quality and impact of service quality and consumer characteristics on channel selection", British Food Journal, Vol. 117 Issue: 8, pp.2078-2097, 2015

21. doi.org/10.1108/BFJ-12-2014-0431

22. Cronin, J.J. Jr and Taylor, S.A. (1992), “Measuring service quality: a re-examination andextension”, Journal of Marketing, Vol. 56 No. 3, pp. 55-68.

23. Atilgan, E., Aksoy, S. and Akinci, S. (2005), "Determinants of the brand equity: a verification approach in the beverage industry in Turkey",Marketing Intelligence \& Planning, Vol. 23 No. 3, pp. 237-248.

24. Nakhai, B. and Neves, J.S. (2009), "The challenges of six sigma in improving service quality", International Journal of Quality Reliability Management, Vol. 26 No. 7, pp. 663-684.

25. Gronroos, C.,"A Service Quality Model and Its Implications" European Journal of Marketing, pp836-844, 1984

26. Dabholkar, Pratibha A., C. David Shepherd, and Dayle I. Thorpe. "A comprehensive framework for service quality: an investigation of criticalconceptual and measurement issues through a longitudinal study." Journal of retailing 76.2, 139-173, 2000

27. Cronin, J. and Taylor, S.," Measuring service quality: A reexamination and extension" Journal of Marketing,Vol. 56, No. 3, pp. 55-68, 1992 
28. Nigel F. P., "The effects of customer satisfaction measurement: the internal market versus the external market", Marketing Intelligence \& Planning, Vol. 14 Issue: 4, pp.9-15, 1996, doi.org/10.1108/02634509610121514

29. Ohmae, Kenichi , "The Mind of the Strategist", McGraw-Hill, Inc., 1982

30. Schneider, B., \& Bowen, D. E," Winning the service game”, Boston, MA, Harvard Business School Press, 1995

31. Rust, R.T., Zahorik, A.J. \&Keiningham, T.L.,"Return on Quality (ROQ): Making Service Quality Financially Accountable.”, Journal ofMarketing, 59, 58-70, 1995

32. Gummesson, Evert, "Quality Management in Service Organizations", New York:International Service Quality Association, 1993

33. Strong, H.,"Marketing and Management Models: A Guide to Understanding and Using Business Models", New York City, Business Expert Press, 2014

34. Zeithaml,V., Bitner, M., \&Gremler, D.," Services Marketing (4th Edition)", New York City, McGraw-Hill, 2006

35. Heskett, J., Sasser Jr. W. E., \& Schlesinger, L..”The Service Profit Chain: How Leading Companies Link Profit and Growth to Loyalty, Satisfaction, and Value", New York, Free Press, 1997

36. Bruhn, M., \&Georgi, D.,"Services Marketing: Managing the Service Value Chain", London, Pearson Education, 2006. 